\title{
TRANSFORMATION OF RURAL SETTLEMENT IN BASUDEBPUR \& JEMARI VILLAGE OF SALANPUR, PASCHIM BARDHAMAN, WEST BENGAL
}

\author{
Sumana Nandi ${ }^{1}$ and Tapas Mistri ${ }^{2}$ \\ ${ }^{1}$ Research Scholar, ${ }^{2}$ Assistant Professor, \\ Department of Geography, The University of Burdwan, Burdwan, India \\ Email: sumananandi93@gmail.com, tapasam76@gmail.com
}

\begin{abstract}
Rural society is going through the changes. The disintegration of large family units into nuclear family units, changes of tastes and values followed by politico-economic practices under the influence of the expansion of education, cultural diffusion that have brought down a sea changes in the size, form, pattern \& structure of the rural settlements. The changes in the settlement may be called a "Transformation". That indicating a major socio-cultural shift of the rural society. The current study on rural settlement transformation is mainly devoted to identify major transformation occurred in the study area from 1971 to 2018, and people's satisfaction with this changes to find out further transformation method at the micro level. Transformation of rural settlement is measured by various spatial, socio-economic, demographic Indicators, with the help of Topographical Fig., Google Earth Image in ARC-GIS platform. It is established in the course of study that, the Spatial- socio-cultural-functional landscape undergoing a significant transformation as evidenced by changing street network pattern, settlement area, building structure, utility purpose of land, mode of production, infrastructural services and more over the manner of social behaviour of the rural people.
\end{abstract}

Key words: Rural, Settlement, Transformation, Social shift, Salanpur

\section{Introduction}

The essence of rural settlement transformation is a marked changed in the semblance, form, nature of spatial carrier apropos to the demographic, economic, socio-cultural, infrastructural, and environmental criteria. It is a process of spatial transformation, social transformation and economic transformation with an aim of optimum allocation and efficient management of tangible and intangible element in internal and external systems. Settlement's change is natural, spatial as well as functional in time scale. This change is expressed in two ways: one is the internal change in social behaviours; hence, institutional, structural; and two is the external change in spatial arrangement, i.e., in morphology and functions (Singh, 2012). The traditional form of rural settlement changing slowly but inevitably over the course of time, which results from the socio-economic transformation, better access to services, improvement in living condition and the general 'westernisation of lifestyles' (Nowak \& Tokarczyk, 2013). Development, transformation and improvement of the rural settlement in modern conditions occurs under the influence of natural, industrial, economic, financial, socio-economic, territorial, administrative and a number of others factor provide an opportunity to identify modern trends of development of individual rural settlement, as well as the entire system of rural settlement (Potosyan, 2014). Settlement systems are very dynamic and complex categories, the constant and continuous need for spatial planning and other development policy instrument to have an appropriate scientific exploration of conditions for the existence and the effects of development go in favour of the need for settlement system exploration (Nikola Krunik, 2012). The largest portion of Basudebpur and Jemari village is occupied by coal mine as a result of prominent human activity, rural settlement landscape with different functional activity, lived by different cultural group, traditional cultural imprint on the building architecture give this area a unique identity and a distinctive economic, cultural value. The traditional rural landscape is characterized by the agricultural landscape which includes farmland and farming activity, but the rural landscape of this area is constantly transformed under the influence of socio-economic modifications. Rural settlement offers space for people to live and produce and supplies basic needs in several ways (Cloke, 2013, cited in Tian et al. 2017). Any changes in the rural settlement system will affect the life of individual rural denizens. The current study on rural settlement transformation is mainly about to identify major transformation occurred in the study 
area between1971-2018, people's satisfaction with these changes to find out further transformation method at a micro level. Transformation in Rural settlement system and peoples satisfaction level with these changes and its application on future transformation and planning purpose have not been adequately deliberated.

\section{Objectives}

The main objectives of this study are:

- To identify spatial and demographic transformation of rural settlement.

- To identify socio-cultural-economic transformation of rural settlement.

- Assess Villagers Satisfaction level on their daily activity and on existing services to outline further area of transformation.

\section{Database}

The database of this study is both primary and secondary collected from various sources. Data regarding Settlement area, Road Network is extracted from Topographical Fig.: $73 \mathrm{l} / 13$ (1975), Google Earth Image dated: 1/9/2004, 31/12/2011, and 18/1/2018. Mouza Fig., Existing LULC Fig. of the Study area is provided by the Asansol Durgapur Development Authority. SocioEconomic, Demographic data is obtained from District Census Handbook (1971, 1981, 1991, 2001, and 2011). Primary data is collected from Field Survey (2017-18).

\section{Methodology}

Following the pragmatic worldview and mixed-method approach this study applied both quantitative and qualitative methods as per requirement that best meet the desires and purposes of the research. Transformation of rural settlement is measured by various spatial, socio-economic, demographic Indicator, those are summarized in the following table:

Table 01: Measurement adopted to analyse the Transformation of the Rural Settlement

\begin{tabular}{|l|l|}
\hline \multicolumn{1}{|c|}{ Parameter } & \multicolumn{1}{c|}{ Indicator } \\
\hline $\begin{array}{l}\text { Spatial Transformation of } \\
\text { rural Settlement. }\end{array}$ & $\begin{array}{l}\text { Settlement Area expansion (1975-2001, 2001-2011, 2011-2018), No of } \\
\text { Dwellings (1971-2011), road network density. }\end{array}$ \\
\hline $\begin{array}{l}\text { Demographic } \\
\text { Transformation. }\end{array}$ & $\begin{array}{l}\text { Population Growth rate (1971-2011), Sex Ratio(1971-2011), Population } \\
\text { Density(1971-2011), }\end{array}$ \\
\hline $\begin{array}{l}\text { Socio-Cultural } \\
\text { Transformation. }\end{array}$ & $\begin{array}{l}\text { Literacy rate (1971-2011), Development in Infrastructure (School, water, } \\
\text { Health), Changes in Building type (Past to Present). }\end{array}$ \\
\hline Economic Transformation & $\begin{array}{l}\text { Level of employment (1971-2011), Proportion of population engaged in } \\
\text { non-agricultural activity (1971-2011). }\end{array}$ \\
\hline $\begin{array}{l}\text { Villagers Satisfaction level } \\
\text { in their daily life and } \\
\text { activity. }\end{array}$ & $\begin{array}{l}\text { Satisfactionlevelin-a.WaterFacility.b.EducationalFacility.c. Health Facility. } \\
\text { d. Marketing. e. Transport. f. Entertainment. g. Visiting. In the scale of - } \\
\text { Good/Moderate/Bad. }\end{array}$ \\
\hline
\end{tabular}

The vector data regarding to the rural build up area is extracted from Topographical Fig and Google Earth image by digitization method, manually tracing the boundaries of settlement area in ARC GIS Software (10.3) in shape file format.

Spatio-temporal dynamic change of rural settlement are analysed by employing the Rural Residential Land Percentage to study the spatial distribution of rural settlement. The rural residential development index was applied to study the spatial variance of rural residential development (Tian, 2007), expressed as follows:

$\mathrm{PR}=\mathrm{RL} / \mathrm{TL} \times 100$

Where, $P R$ is rural residential land percentage of the study area, $R L$ is rural residential land area of the study area. $\left(\mathrm{km}^{2}\right), \mathrm{TL}$ is total land area of the study area $\left(\mathrm{km}^{2}\right)$.

$\mathrm{SI}=\boldsymbol{\Delta} \mathrm{RLij} / \mathrm{TL} \times 100$

Where, $\mathrm{Sl}$ is the Settlement Expansion index of the study area from period $\mathrm{i}$ to $\mathrm{j}$ and $\boldsymbol{\Delta} \mathrm{RLij}$ is the rural residential development from period $\mathrm{i}$ to $\mathrm{j}$.

100 household in the study area (50 household from each village) were selected by simple random sampling method. A total of 100 people from each household participated in a face to face semi-structured questionnaire survey in 2018. 
Tabulation, Calculation and statistical representation of primary and secondary data are done in Micro Soft Excel 2010. Required Fig. is prepared in ARC GIS Software (10.3).

\section{Study Area}

The present study area Basudebpur (JL.NO. 31) and Jemari (JL.NO. 32) Mouza is located in Basudebpur- Jemari Gram Panchayat of Salanpur C.D. Block in Paschim Bardhhaman district at the Indian state of West Bengal (Fig.: 1). This two mouza is located in the south-western part of Salanpur and the geographical coordinate of this area is defined by the latitude $23^{\circ} 46^{\prime} 42^{\prime \prime} \mathrm{N}$ to $23^{\circ} 48^{\prime} 13^{\prime \prime} \mathrm{N}$ and longitude $86^{\circ} 52^{\prime} 22^{\prime \prime} \mathrm{E}$ to $86^{\circ} 53^{\prime} 33^{\prime \prime} \mathrm{E}$. Total administrative area of Basudebpur and Jemari is 1.62 sq. $\mathrm{km}$ and 1.51 sq. $\mathrm{km}$, which encompasses 2.32 percent of Salanpur (District Census Handbook of Bardhhaman, 2011). These undulating area is covered by laterite soil. Natural vegetation is almost absent in this area. Howrah-Patna-Mughal Sarai line passes through this area and Rupnarayanpur rail station is around $3.57 \mathrm{~km}$ (road distance from main settlement area to rail station) towards north-west from the area. The main settlement area is around $1.12 \mathrm{~km}$ away from the G.T. Road. Approximately 0.61 sq. $\mathrm{km}(19.49$ percent) area is utilized for mining activity (ADDA). Basudebpur and Jemari village located in North direction of the mine.

\section{Figure 01: Location of the Study Area}

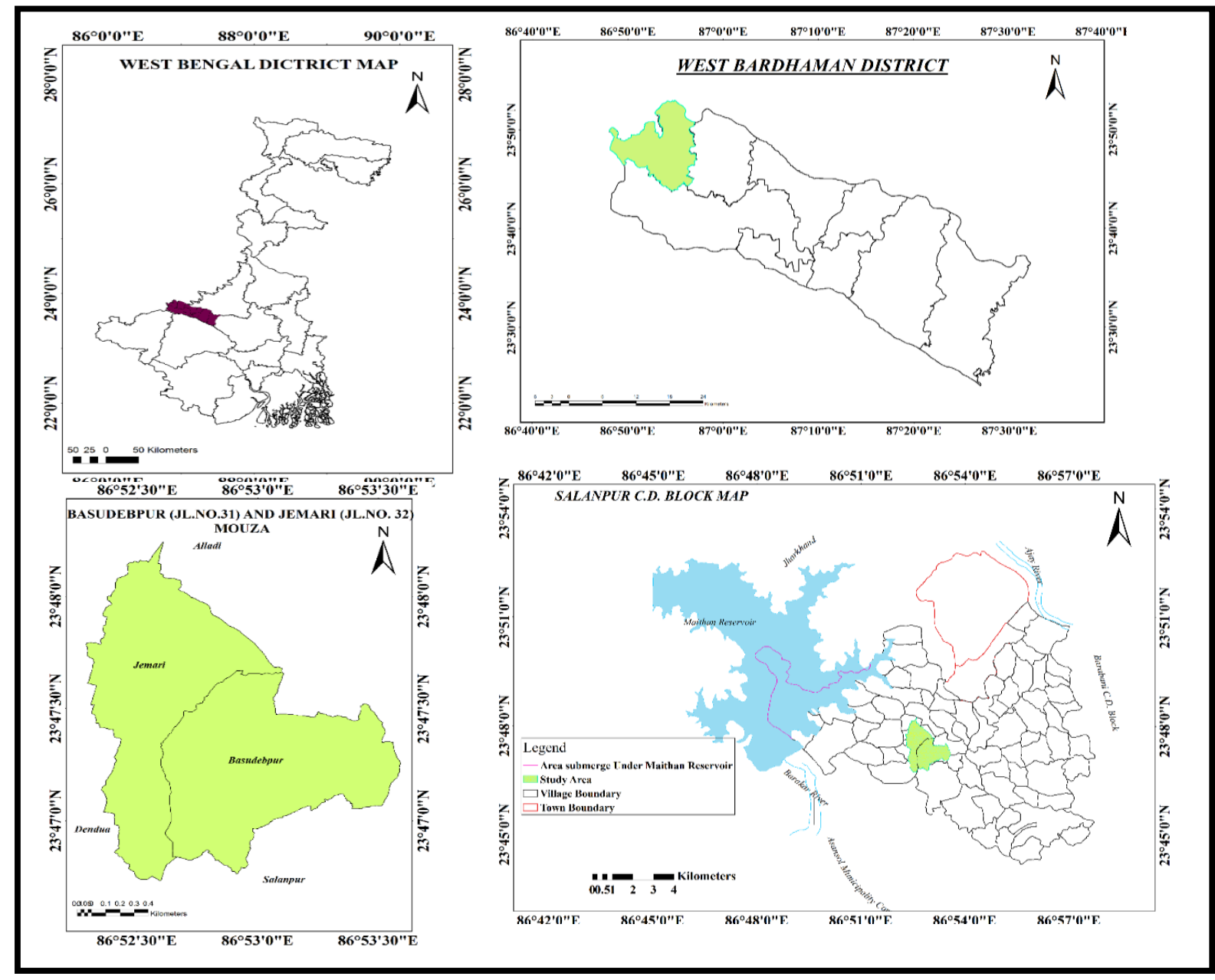

\section{RESULT AND DISCUSSION}

\section{Spatial Transformation of Rural Settlement}

In Spatial aspect, the transformation process of rural areas could best possibly defined through observing the character of its morphological forms, that consist of land use pattern, street network and building (Purnamasari et.al., 2017).Measurement were conducted using statistical data obtained from analysis of $-a$. Percentage of rural residential land area, b. rural settlement expansion index, c. number of rural dwelling, $d$. transformation of road connectivity.

\section{Rural Settlement in 1975}

In 1975, rural settlement of Basudebpur, Jemari village is characterised by low building density, few rural dwellings concentrated in small areas. Except G.T. road all street network are unmetalled road (Table: $2 \& 3$ ), (Fig.: 2). 
Table 02: Rural Residential Land Percentage, Expansion Index, Road Density and Nature of Road in Basudebpur and Jemari (1975-2018)

\begin{tabular}{|c|c|c|c|c|c|c|c|}
\hline Year & $\begin{array}{c}\text { Settlement } \\
\text { Area (Sq. } \mathbf{~ k m})\end{array}$ & $\begin{array}{c}\text { PR Index } \\
(\%)\end{array}$ & SI (\%) & $\begin{array}{c}\text { Road Length } \\
(\mathbf{k m})\end{array}$ & $\begin{array}{c}\text { Road Density/ } \\
\text { Km. }\end{array}$ & $\begin{array}{c}\text { Metalled } \\
\text { Road (km) }\end{array}$ & $\begin{array}{c}\text { Unmetalled } \\
\text { Road (Km) }\end{array}$ \\
\hline 1975 & 0.12 & 2.59 & 0 & 8.48 & 2.71 & 0.75 & 7.73 \\
\hline 2004 & 0.15 & 4.81 & 47.84 & 10.33 & 3.30 & 6.8 & 3.53 \\
\hline 2011 & 0.21 & 6.73 & 41.38 & 10.33 & 3.30 & 6.8 & 3.53 \\
\hline 2018 & 0.28 & 8.97 & 48.28 & 10.69 & 3.42 & 8.16 & 2.53 \\
\hline
\end{tabular}

Source: Topographical Fig. \& Google Earth Image

Table 03: Total Number of Dwellings in Basudebpur and Jemari (1971-2011)

\begin{tabular}{|c|c|c|}
\hline \multirow{2}{*}{ Year } & Basudebpur & Jemari \\
\cline { 2 - 3 } & Total no. of dwellings & Total no. of dwellings \\
\hline 1971 & 247 & 406 \\
\hline 1981 & 298 & 787 \\
\hline 1991 & 412 & 861 \\
\hline 2001 & 471 & 721 \\
\hline 2011 & 587 & 795 \\
\hline
\end{tabular}

Source: District Census Handbook (1971 to 2011)

\section{Rural Settlement in 2004}

From 1975 to 2004, in general the rural settlement area increased significantly at the rate 47.84 $\%$ in between 1975-2004. Number of rural household is also increased in the study area. Road length increased and the proportion of metalled road is also improved simultaneously (Table: 2 \& 3). Settlement area is mainly expanded along the transport line and few settlements also increased near Vagran colony of Basudebpur mouza situated near Bonjhemari Coal mine.

Figure 02 to 05: Rural Settlement in different years
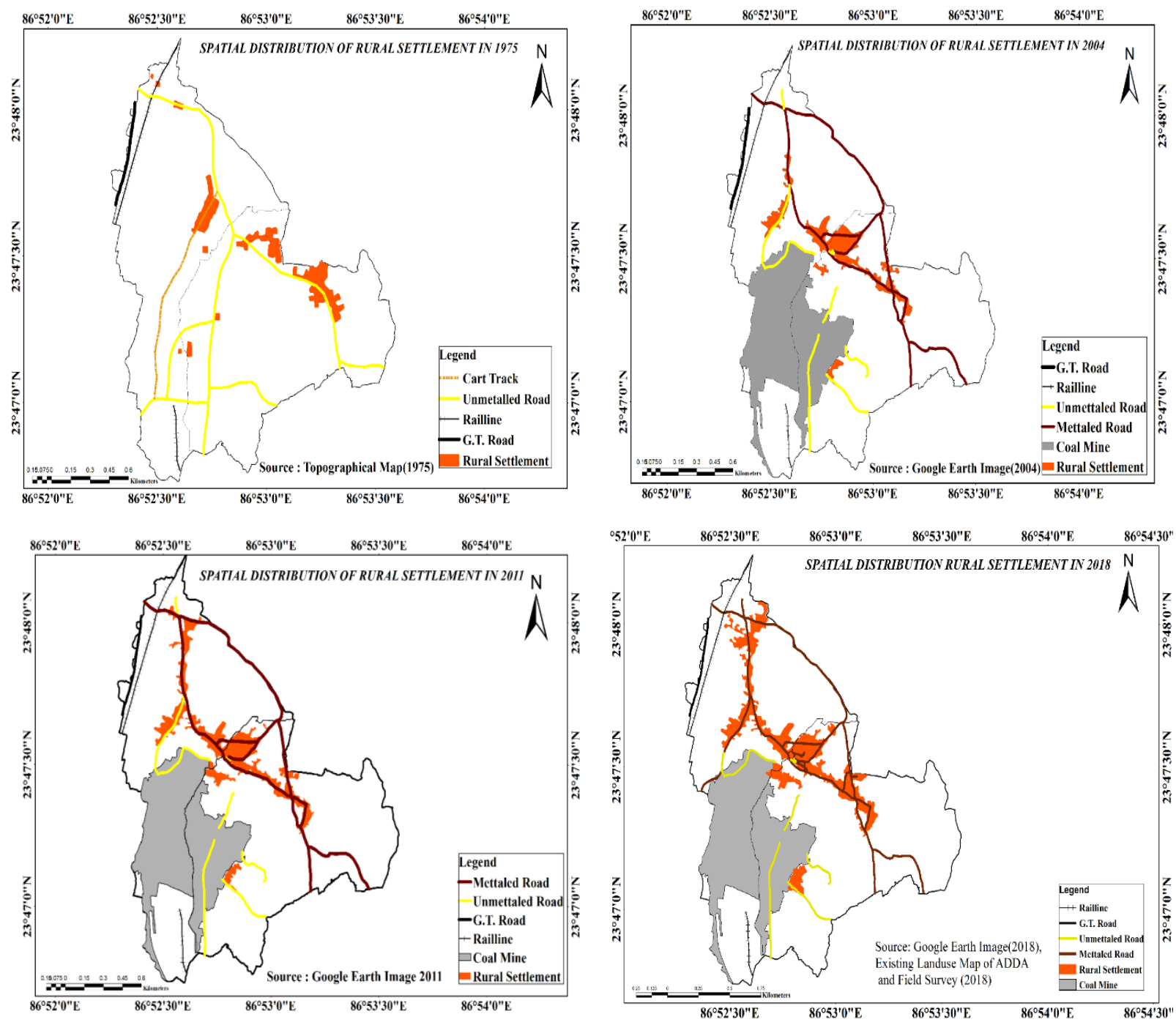


\section{Settlement in2011}

Analysis of Google Earth Image 2011 concretization of street network and growth of settlement area is a continuous process along with the increased of rural household. Expansion of rural settlement mainly occurred along the transport line towards the main G.T. road (Table: $2 \& 3$ )

\section{Rural Settlement in 2018}

From the analysis of Google Earth Image 2018, with the help of existing land use Fig. of ADDA and repeated field survey explore many issues of spatial characteristics of rural settlement in these two mouza. Settlement area, road density, rural buildings are increased at the same time (Fig.: 5). But the fact is build up area expanded much unplanned way (Table: 2\& 3).waste dumpsite of Bonjhemari coal mine, which is very much dangerous for the local people .People living next to coal mine dump not only suffered from health risk and environmental pollution, but blasting in coal mine make many cracks in the household, local people always live in a risk of the subsidence of huge blocks of dumping material.

\section{Demographic Transformation}

Demographic change is the accompanied process of rural settlement transformation. Population trends and structures are an important indicator of socio-geographic conversion of the given area.

Figure 06-07: Population Growth Rate and Density of Basudebpur \& Jemari (1971-2011)
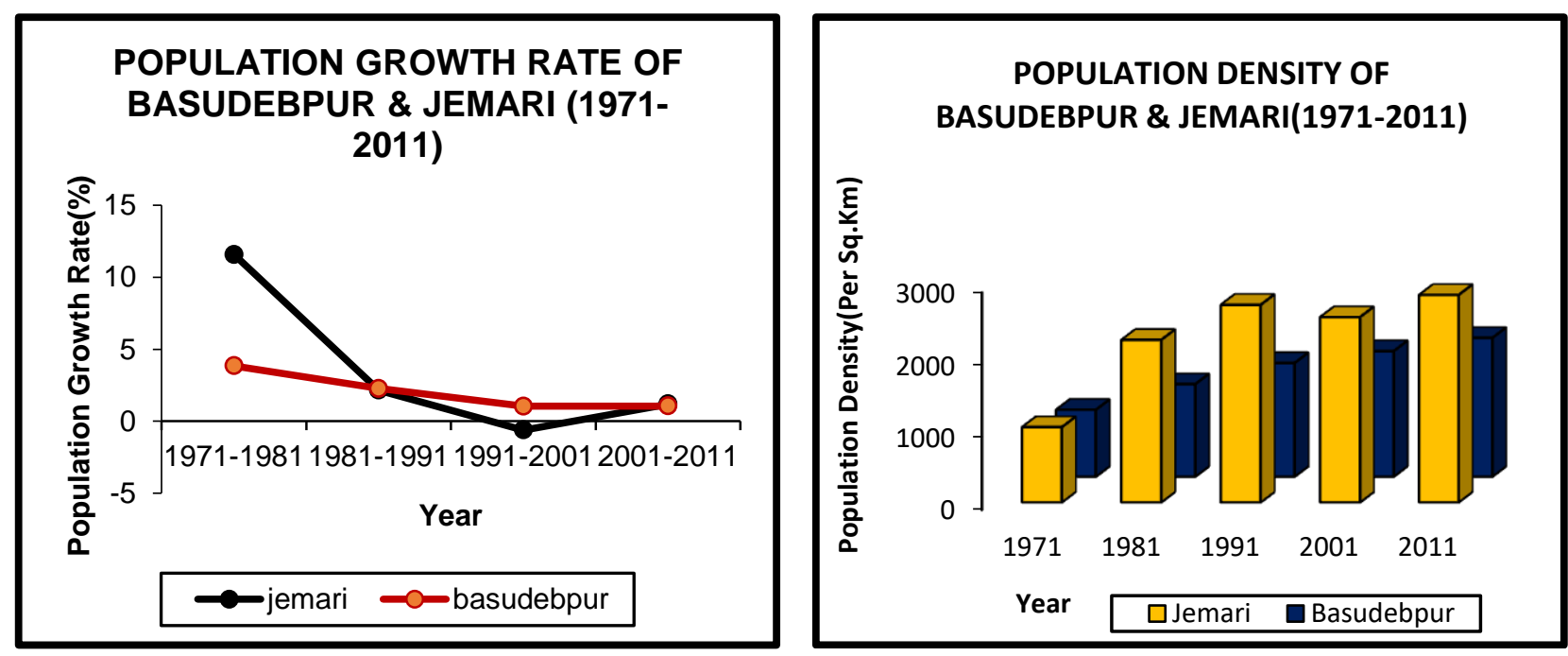

In between 1971-2011, population growth rate of Jemari and Basudebpur is declining, with minor variation, this may be considered as stabilization stage. But, there is inter village difference between Jemari and Basudebpur. In between 1971-1981 population growth rate is very high in Jemari (11.84 percent), accompanied by Basudebpur (3.84 percent). Demographic changes much occurred at much the same time neither because of close interrelation nor because of coincidence but because they are all products of massive social and economic changes (Caldwell et.al 1988). Social and economic process of these two villages is very much related with the mining industry.

The post-nationalization era opens various employment opportunities, which fascinate many people to settle down in this area. In 1991-2001, negative phenomena that accompany depopulation processes occurred in Jemari include negative population growth, decreasing population density, and declining rural dwellings. The depopulation of these villages in this time mainly due to the diversification of economic powers of this area. From ancient time Jemari is the main market centre of Salanpur but with the passage of time due to various social and economic disorganization and emergence of new market centres in surrounding areas (mainly in Rupnarayanpur, Samdi, Dendua) this place has lost its attractiveness and due to growth of accessibility in different places people's loss their interest in these market, many people migrated to nearby cities and city surrounding area search for better opportunity. Besides this period population is continuously increasing in both the villages. Sex ratio structure is quite discouraging for Basudebpur and Jemari. In 1971-2001, sex-ratio is declining for both 
Basudebpur and Jemari but in 1981 sex-ratio of Jemari highly increased. after that Period it is again decreasing. But in recent time period it is slightly improved for both the villages.

\section{Socio-Cultural Transformation}

Socio-cultural transformation of any settlement is closely associated with its changing literacy level of its settled people, transforming building architectural structure and material, improvement in public facilities like water, health, transportation-communication, educational infrastructure, entertainment and internal changes in social behaviour. During the passage from underdevelopment to development, several interrelated processes occur simultaneously (Abdullah, 1987). The settlers have made several adjustments in consecutive stages for the needs of survival, sustenance and extension. Alteration of numbers and distance range of public facilities is important affecting factor for the transformation process of rural settlement. In 1971 , pond and well are the main source of drinking water in the study area, but in later period it is supplemented by tube well, and tap water. The reach distance towards this facility is also decreased. The improved road transport network towards the main road encouraged many outsiders started hotels, retail shop, tea shop, small business etc. In present time many "auto rickshaws" are available from the centre settlement towards the main road for travelling. This improved facility increased mobility of the rural denizens, especially for women and teenager group. Many women's go to nearby cities and surrounding areas for working and marketing purpose, young generation go to their tuitions, training centres, school, college etc. From many years Basudebpur Primary School (established in 1946) serving in these two villages. Jemari Primary school started in 1991, and in 2011 two pre-primary schools started in Basudebpur and Jemari respectively. One middle school established in Basuebpur in 2011. Nearest higher secondary school located in Achchra village. Two ICDS centres are established in 2010 and 2014 respectively in Basudebpur and one Sishu Siksha Kendra established in 2012 at Vagran colony. So, the access to elementary education is also increased. Literacy level of these two villages is increasing but male literacy rate is decreasing comparing to female literacy (Census of India). This phenomena is very much related with the economic environment of this area. Male populations are joining as a casual labour or other work in the coal mines for the sake of employment in very younger age sacrificing their education but Women's at least complete their elementary education. But in terms of health facility this area is not so much developed. There is no primary health centre or sub centre, from the very beginning. The distance between nearest Primary Health Centre (located in Kallya) and main settlement area is $3.98 \mathrm{~km}$. Recently one primary health sub centre established in Jemari. From 1981, these two villages are electrified but the Vagran colony is not connected to the Govt. electric lines, very low quality electricity is provided by the ECL in this colony. Street lightening through Solar Light Development Scheme is also implemented. To this was community Hall, ration shop, cyber café, retail shop, playground, reconstruction of burial grounds for different community (Muslims and Baishnav) were also added. Core of the settlement geography is building (R.Y. Singh). Changes in architectural structure, building materials, house types are an important indicator of the socio-cultural transformation of rural settlement. According to field survey, among 100 household 32 household are kuccha house made by mud, tiles, thatch and other material, consisting mainly of 1 or 2 dwelling room in between 10-20 years ago. But they now build pucca houses made by brick, stone with several rooms for separate purpose. Old houses of this two villages have courtyards surrounded by walled rooms are visualized, this style is rarely found in modern type of dwellings. Transformation and improvement of dwelling house is occurred in the main settlement area But in the satellite settlement of Vagran colony dominated by Schedule caste group having poor contact with the main settlement area lived in very poor housing condition having one or two dwelling room, poor drainage facility, narrow unmettaled road and far away from public utility services (Primary school, health, retail shop etc.).

\section{Economic Transformation}

In Basudebpur and Jemari village the spatio-fuctional organization of rural settlement reveal that houses are constructed at once site form a village, the surrounding space is occupied by agricultural fields, fallow land and coal mine in the southern direction. Roadside settlement towards the main road constructed mainly for commercial cum residential purpose. Working opportunity in the coal mine encourage people to build houses in vagran colony. Peoples of this satellite settlement mainly work in the coal mine as a casual labour, some of them also have permanent job in the mine. Economy of the people of these two villages mainly depends on mining activity. Some Muslim people engaged in agricultural activity, they mainly keep stay the agricultural practice alive in these area. Other workers worked at private factory, running self- 
business, hotels, retail shops etc. Economy of this rural settlement primarily lost its primary rural characteristics changing its production system by 'Deagrarianization' and developed a more complex economic structure (Njegac \& Toskic, 1998). The transformation of economy of rural settlement is closely related with the change in Work Participation Rate, and with a growth of non-agricultural activity. In between, 1971-1981 overall dependency on agricultural activity is decreasing and Work Participation Rate is slightly declining in present time. Work participation rate is very low for women, 5.94 percent and 7.24 percent for Basudebpur and Jemari respectively (Census of India, 2011). During the field survey it is revealed that, many women of vagran colony worked in mine along with their domestic work in a flexible time (between 5 am to $7 \mathrm{am}$ ) as a casual labour.

Figure 08-09: Work Participation Rate and People Engaged in Non-Agricultural Activity
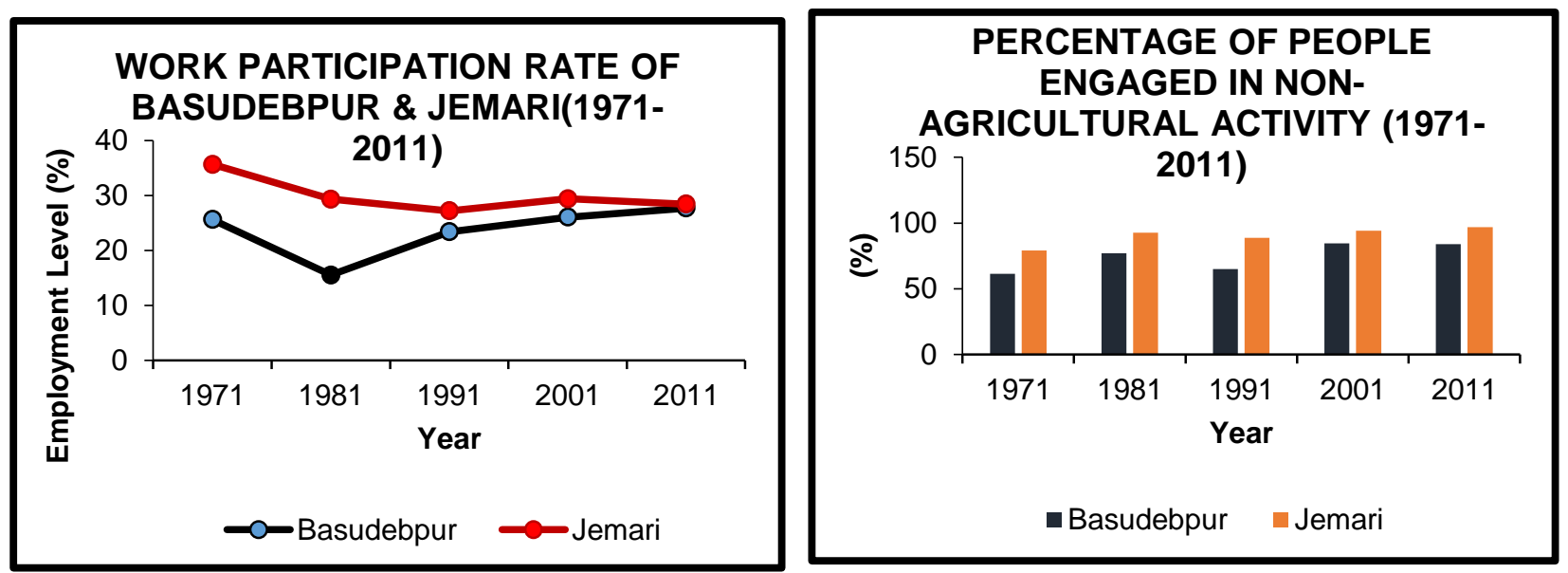

Source: DCHB (1971-2011)

\section{Peoples Satisfaction Level in their Life}

This gratification levels indicates individual perceptions about their life. The result shows that peoples are quite satiate pertaining to marketing and visiting conveniences. Marketing in the study area refers to the activity of attending "rural market", that occurs twice per week in Thursday and Sunday respectively. Such a market is an important place for rural people to purchase goods or sell their own farm products (Liang et.al, 2002 \& Skinner, 1985, cited in Tian et.al, 2017).Visiting with relatives and friends in locale and in neighbouring villages is an important part of rural society. It influences employment, culture, and mental health of people (Kipnis, 1997, cited in Tian et.al, 2017). People's attitude concerning water and educational facility is moderate.

Figure 10: Peoples Satisfaction Level

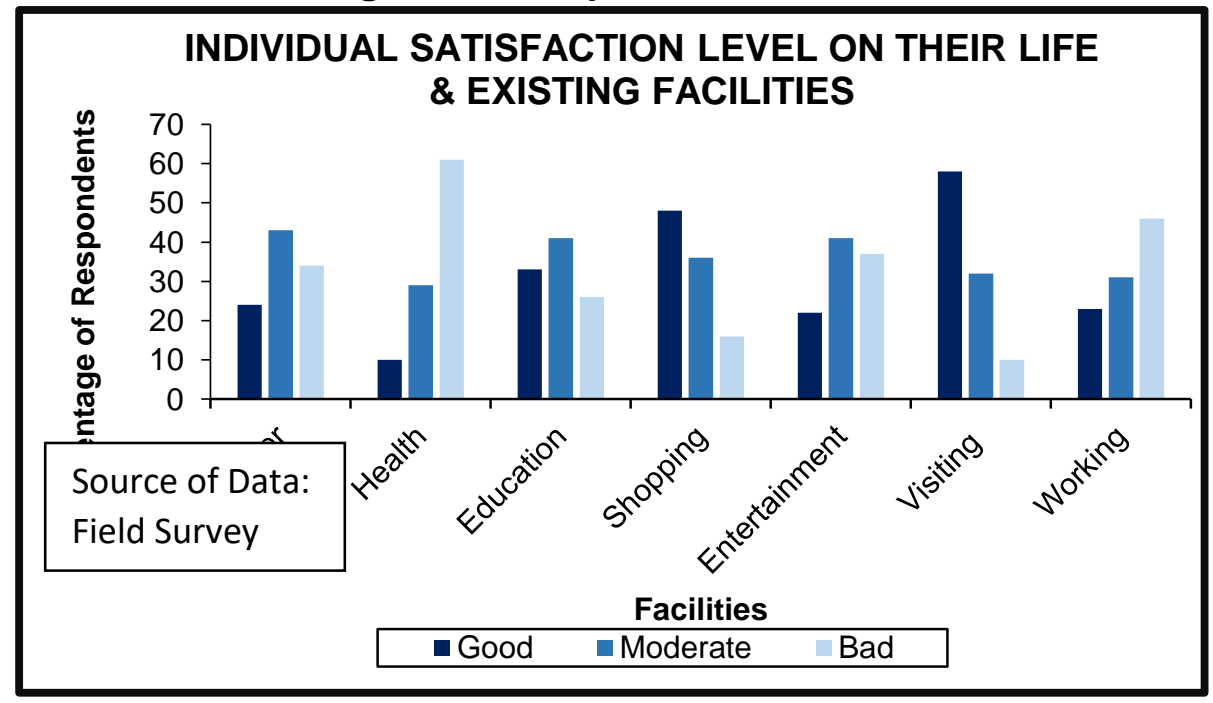

For elementary and primary level education existing educational facility is satisfactory but access to higher educational facilities is difficult for the young generation. Working activities include farming and non-farming activity. Interaction with the local peoples revealed that peoples are not so much satisfied working in coal mine, because maximum employed people in 
mines are casual labour at very low wages and working in a very deteriorating environment. Agriculturalist is not satiate with the water facility required for cultivation and young educated generation grieved in unemployment and underemployment. Peoples seeking entertainment demand park and playground in nearby area. Worst condition is found in health facility. Peoples are forced to depend on medical facilities of cities, which need serious attention. Question is asked to the local people that are you willing to go other places in future to live? 52 people answered "yes" we are. 18 people answered "no", and 30 people answered we are worried about the cost of relocation.

\section{Conclusion}

It is established in the course of study that, the transformation occurring today in the traditional settlement system in the sphere of society, culture, economy to the study area. Settlement expansion is driven by the development of street network and its surrounding economy. The socio-cultural-functional landscape undergoing a significant transformation as evidenced by changing street network pattern, settlement area, building structure, utility purpose of land, mode of production, public utility services and more over the manner of social behaviour of the rural people. In the study area investors in terms of real estate developer have not appeared significantly but the development of road, public utility services and the social investment by public sectors are very important that leads to be ultimate transformation in the site, shape and direction of settlement and also the taste of the inhabitants, which may ensure "rural urbanization" in the villages. But, in the villages of developing countries it is a common problem that they are getting urbanized in terms of demographic, economic and spatial characteristics but the standard of living is not improved as urban area. It is also evidenced in the study that peoples demand in their daily available facility is not fulfilled properly. Every household not get proper access to improved water facility and sanitation infrastructure. It has been revealed by the result obtained, that people's attachment to the soil and settlement is diminishing and they are more willing to migrate in nearby city or city surrounding areas for better opportunity and life style. Instead of family solidarity and continuity, the growth of individualism and nuclear family is more prominent. Caste is no longer a sole and final decisive factor of occupation. A kind of loosening is seen in the primitive caste and religion segregation. Segregation by occupation or social status is seen in some part of the village (Vagran Colony). Prohibition of inter dining is also maintained during many festivals. Change is a natural process, transformation in the rural settlement landscape in the study area have many positive and negative impacts. "Deagrarianisation" with in the rural landscape, growth of non-agricultural activity, unplanned and haphazard growth of rural houses in the unstable area must destroy the character of traditional rural landscape.

\section{References}

1. Aleksandar, T. \& Njegac, D. (1998) Rural diversification and socio-economic transformation in Croatia.GeoJournal, 46(3), 263-269. Springer Publication. Retrieved from: http:// www.jstor.org/stable/41147297

2. District Census Handbook (2011) Census of India (2011), Series 20, Part XII-A, Directorate of Census Operations.

3. Land Use and Development Control Plan - 2025 for Asansol Sub-division. Asansol Durgapur Development Authority.

4. Nowak, A. \& Tokarczyk, N. (2014) Transformations of traditional land use and settlement patterns of Kosarysche Ridge (Chornohora, Western Ukraine). Bulletin of Geography: Socio-economic Series, 24 (2014), 191-201. DOI: http://dx.doi.org/10.2478/bog-2014-0022

5. Potosyan, A.H. (2016) The main factors of development and transformation of the mountainous countries. Annals of Agrarian Science. Retrieved from: https://doi.org/ $10.1016 /$ i. aasci.2016.09.013

6. Purnamasari, L.S., et.al (2017) Spatial Transformation of Surakarta's Peripheral Rural Villages Under In-Situ Urbanization Phenomena: The Case of Gentan Village. Journal of Geomatics and Planning, 4(1), ISSN 2355-6544, 83-96. Doi: 10.14710/geoplanning.4.1.

7. Singh, R.Y. (2012) Geography of Settlement. Rawat Publication, 1-35, ISBN 81-7033-209-

8. Tian, Y., et al. (2017) Restructuring rural settlements based on subjective well-being (SWB): A case study in Hubei province, central China. Land Use Policy, 63 (2017), 255265.Retrieved from:http://dx.doi.org/10.1016/j.landusepol.2017.01.038 